\title{
Necessary Questions of Chö: Uses and Abuses of Religion in Dondrup Gyel's “Tulku”
}

\section{Catherine Hartmann}

"Why do you ask questions of roots and branches instead of the necessary questions of chö (Tib. chos)?" asks a character in Tibetan author Dondrup Gyel's (don rgrub rgyal) controversial 1980 short story, "Tulku" (sprul sku). The Tibetan term chö can be translated in many ways, including to mean 'the Buddhist teachings,' 'religion' more generally, or even 'the nature of reality.' In "Tulku," however, what chö means is not at all clear, and the various characters claim authority to determine what is legitimate chö. In the story, a Tibetan village is visited by a mysterious stranger claiming to be a tulku-a reincarnated religious leaderbut who is actually a fraud. Most scholars have interpreted "Tulku" as a critique of traditional Tibetan religious devotion, and as a call by Gyel for Tibetans to modernize. This paper, however, proposes a new reading of "Tulku." It suggests that Gyel pairs overt criticism of the corrupt tulku with a subtler critique of the Chinese government's policy towards Tibetan Buddhism. It argues for such a reading by tracking how the word chö is used in "Tulku." It shows that Gyel places the word not in the mouths of the Tibetan villagers, but rather in the mouths of the fraudulent tulku and the representatives of the Communist Party. Both thus use chö in order to appeal to the Tibetan villagers, claim power for themselves, and exclude the opposing party. "Tulku" thereby creates parallels between the ways in which the Tulku and the Party use chö to appeal to and manipulate the Tibetan villagers. On this reading, "Tulku" highlights the way chö can be weaponized by both traditional religious authorities and Communist party ideology, and suggests that in this modern period, any claimant to chö must be treated with caution and skepticism.

Keywords: contemporary Tibetan fiction; Dondrup Gyel; Tibetan Buddhism; Tulku 
"Why do you ask questions of roots and branches instead of the necessary questions of chö (Tib. chos)?" asks Akhu Nyima, a character in Tibetan author Dondrup Gyel's 1980 short story "Tulku” (sprul sku) (Bhum 1994: 213). ${ }^{1}$ The Tibetan term chö can be translated in many ways, including to mean 'the Buddhist teachings,' 'religion' more generally, or even 'the nature of reality.' In "Tulku," however, what chö means is not at all clear, and the various characters claim the authority to say what counts as legitimate chö. As such, we can read Gyel's entire short story as an attempt to ask arguably the most necessary questions of chö: what is chö and who gets to say so?

In "Tulku," Akhu Nyima's family is visited by a mysterious stranger who claims to be a tulku-a reincarnated religious leader-but who actually turns out to be a fraud. Though internal critiques of the tulku system and the notion of a fraudulent tulku have long been present in Tibetan Buddhism, the story stirred up controversy upon publication, with many Tibetans interpreting the story's corrupt tulku as evidence of Gyel's anti-clerical stance towards Tibetan religion. Gyel even received death threats from people who read the story as damaging Buddhism and betraying the cause of Tibetan religious liberty. Scholars, too, have mostly understood "Tulku" as a critique of Tibetan Buddhism and a call for modernization.

Such interpretations, however, fail to recognize that Gyal's overt critique of corrupt tulkus is paired with a subtler critique of the Chinese government's policy towards Tibetan Buddhism. Such a critique had to be made lightly, for while the 1980 s were a time when the Chinese government was loosening censorship restrictions and allowing Tibetans to write about religion, any criticism of the government or the Communist Party was strictly prohibited. Reading "Tulku" against the grain of its censor-approved and apparently pro-Party stance, I suggest that we can interpret "Tulku" as critical of both traditional Tibetan religious authorities and of the Chinese government for trying to monopolize control of religion, and of using it to manipulate the Tibetan people. It is, of course, difficult to read between the lines of censorship, or to claim to know an author's intentions, and so I present this reading of "Tulku" as but one possible reading among many.

There is, however, textual evidence to argue for this interpretation. Such evidence emerges when we track the use of the word chö in "Tulku," and trace the patterns of who uses the word and to what purposes. Close analysis reveals that the Tibetan villagers, by and large, do not use the word. Rather, it is the tulku and representatives of the Communist Party who deploy it, each in order to undermine the opposing party in the eyes of the Tibetan villagers, and thereby enhance their own prestige.

This is most obvious in the case of the fraudulent tulku, who clearly uses claims to chö as a screen obscuring his greed and lies. He deflects criticism and uncomfortable moments by changing the subject to "what's important for us chö practitioners (nga tsho chos pa rnams la nye bar mkho ba ni...)" (Bum 1994: 209). But, in the story, the tulku's claims to chö are mirrored by the Party's claim to define, protect, and regulate chö. For instance, the policeman who arrests the fake tulku, declares: "When we implement the party's policy of religious freedom, you must distinguish well between friends and enemies (Tang gi chos dad rang mos kyi srid jus lag len du bstar skabs/ ci nas kyang dgra gnyen gyi dbye ba legs por "byed dgos)" (ibid: 213). In each case, one party claims the authority to know what proper chö is. The Party's claims are not revealed to be as obviously fraudulent as the tulku's, (such claims would not have passed the censors, in any case), but the parallel usages of chö by the tulku and representatives of the Party suggest Gyel is framing the tulku and the Party as foils for one another. As such, he uses the story to suggest that each of their claims to chö should be regarded with skepticism.

The story depicts chö, then, as a contested category, one which multiple parties claim the authority to define. Chö, like 'religion,' a term that is often used to translate chö, has no universally agreed-upon definition. People generally agree that it refers loosely to 'what is right,' but what exactly counts as chö, and who gets to say what counts as chö, is not fixed from the outset, but determined through a social and discursive process. In effect, the term chö is part of a discursive strategy of defining what counts as real chö, and of authorizing the speaker as one who gets to determine what counts as real chö. What more, these appeals to chö anchor the sort of discourse Bruce Lincoln defines as something "strategically employed to mystify the inevitable inequalities of any social order and to win the consent of those over whom power is exercised," allowing both the tulku and representatives of the Communist Party to claim mastery over chö and thereby assert authority over the Tibetan villagers (Lincoln 2014: 4).

In such an environment, where religion/chö itself is a contested category, Gyel frames the project of distinguishing true and false religion as a fraught, but necessary endeavor. Gyel calls for Tibetans to interrogate not merely their own tradition, but also those who would invoke that tradition to advance their own aims. Whereas Tibetans once might have been able to rely on the institutions 
around them, the new post-Cultural-Revolution world requires renewed inquiry into the motives of supposed authorities on religion. The only way of knowing true religion from false, Gyel suggests, is to ask the necessary questions.

In order to argue for this interpretation, I will first introduce Dondrup Gyel and the social and literary context in which he wrote "Tulku." I will then present a synopsis of the short story, and review existing scholarly interpretations. Then, I will turn to the "Tulku" itself, and analyze the uses of the word chö in "Tulku" in order to demonstrate patterns of usage.

This essay reframes our understanding of Dondrup Gyel, often lauded as the father of modern Tibetan literature, and his most controversial work (Hartley and SchiaffiniVedani 2008: 4). To date, scholarship on Gyel has treated "Tulku" only briefly, as though scholars have been puzzled over what to do with this controversial short story. What has been written on "Tulku," moreover, generally concerns a broad overview of the plot-namely that a tulku comes to town, ingratiates himself with the villagers, and turns out to be fraudulent-rather than detailed textual analysis of the story itself. This essay thus digs deeper into "Tulku" to appreciate Gyel's sophisticated rendering of Tibetan village life after the Cultural Revolution, and his skepticism both towards traditional religious devotion and towards the Chinese government's promises of religious liberty. Such a reading thus advances our understanding of Gyel's continued attempts to navigate tradition and modernity.

This reading of Gyel's work also highlights a point that is important to scholars of religion more generally. Namely, that 'religion' itself is a contested category. As such, scholars should pay attention to how 'religion' is invoked and either implicitly or explicitly defined by competing groups. They should also mark how these competing definitions participate in discourses that elevate one group or another. Scholars, too, must ask the necessary questions of religion.

\section{Dondrup Gyel, "Tulku," and the Tibetan Literary Scene of the 1980 s}

Dondrup Gyel (1953-1985) was one of a number of young Tibetan intellectuals who emerged in the early 1980s and published short stories and fiction in new journals such as Tibetan Literature and Art (bod kyi rtsom rig rgyud tsal) and Light Rain (sbrang char) (Shakya 2000). The strict controls of the Cultural Revolution in the 1960s and 1970s were slowly being lifted, allowing Tibetans the freedom to develop, for the first time in Tibetan history, a secular literary culture. Open criticism of the Communist Party was still forbidden, but many works did address the issues facing Tibetan peoples under Communist rule, including a perceived loss of tradition and a pastoral way of life, as well as the difficulties of adapting to modernity. This development of a secular literary culture represented a major departure from most of Tibetan literary history. Tibet had long had a rich and vibrant literary culture, but it was dominated by religious figures writing about religious topics rather than laypeople writing fiction or poetry about modern life. ${ }^{2}$

One major issue these authors addressed was the status of religious figures and institutions. Prior to 1959, Buddhism held a near-monopoly on Tibetan literature, and dominated public life (Gayley and Willock 2016). ${ }^{3}$ A network of monasteries centered on the Ganden government in Lhasa connected the vast landscape of the Tibetan plateau. This united far-flung Tibetan peoples, many of whom lived in remote regions and spoke a variety of languages, into a shared moral and political cosmology. In that cosmology, monks were imagined to possess more merit and be higher in status than laypeople, with senior religious leaders considered to be higher still. Tulku, figures recognized at birth as the reincarnation of important religious leaders, commanded huge amounts of power and respect. Both wealth and literary production were largely concentrated in monasteries. This led some Tibetan writers of the $1980 \mathrm{~s}$ to question whether this system should be reinstated following the Cultural Revolution, or whether Tibetan society should modernize by developing new social institutions.

The Chinese Communist Party, for its part, denounced the traditional Tibetan system as oppressive and theocratic. Buddhism, the Party maintained, was a superstitious ideology that allowed non-productive parasites to impose hardships on the common people, and therefore must be reformed. At first, the Party introduced such reforms gradually, but eventually adopted a policy of more radical change. This reached its height during the Cultural Revolution, when the Party forced thousands of monks and nuns to return to lay life, imprisoned thousands of Buddhist practitioners, and destroyed numerous texts and other religious objects in an attempt to modernize Tibet. Restrictions eased during the late seventies and early eighties, allowing monks to re-join monasteries and religious leaders to resume their posts, but the Party remained deeply critical of religion.

It was in this historical and political context that Gyel wrote "Tulku" (sprul sku), as well as his other short stories 
and poems. The harsh policies of the Cultural Revolution were easing, but they remained a fresh memory. Some Tibetans hated the policies they saw as imposed by the Chinese government, and sought to restore traditional Tibetan religious institutions. Others, however, and in particular the young and well-educated literary cohort of which Gyel was a part, wondered if some efforts to modernize were necessary. They may not have approved of the Party's brutal way of effecting reforms, but they shared some of the same criticisms of the traditional system. In short, it was a time of change and questioning. Tibetans were debating what modern Tibetan society should look like, and what role Buddhism should play in that society. They were also unsure of what policies the Chinese government would impose in the future.

Gyel made these themes of tradition and modernity the core of much of his work. In poetry and short stories such as "Waterfall of Youth" (lang tsho'i rbab chu), "Frost-bitten Flower" (sad kyis bcom pa'i me tog), and "A Threadlike Path" (rkang lam phra mo), Gyel worked to create realistic depictions of Tibetan life that neither glorified traditional Tibetan society, nor denigrated it as hopelessly backwards. Gyel praised the "brilliant accomplishments of the past," but also noted that those accomplishments "cannot serve today's purpose” (Shakya 2000b: 12). He condemned conservatism (rnying zhen) and criticized what he saw as unfair societal practices (Bhum 1994: 26-27). ${ }^{4}$

However, he was also critical of the Communist Party's methods and purposes, and wrote about the hardships imposed by Communist policy in a genre that came to be known as 'scar literature' (Chin. 伤痕文学). Such 'scar literature' emerged in the 1970s and early 1980s, soon after the death of Mao Zedong, and highlighted the sufferings of Chinese people under the Cultural Revolution (Shakya 2000a: 34). He was skeptical about the Communist utopia the Party promised. In a story called "Impermanent Illusory Dream” (mi rtag sgyu ma’i rmi lam), Gyel described a young Tibetan who fully buys into Party values and does everything he can to advance through the hierarchy, but who ends up alone and miserable, having shunned both his past and any meaningful connection to his Tibetan peers. The evocative Buddhist language of the title suggests that traditional admonitions against grasping for material success are not rendered irrelevant by Party dominance, but, if anything, rendered even more important.

As such, Gyel may have been skeptical of traditional forms of Buddhism, and particularly the hierarchies, blind faith, and conservatism they fostered, but this did not make him an adherent of the Party's vision for Tibetan modernization. Instead, he tried to find a new way forward for Tibetans that would draw on Tibet's rich cultural resources while being adequate to the needs of modernity.

\section{Summary of "Tulku"}

"Tulku" takes place in a remote village in Amdo around 1980. Akhu Nyima, a devout former monk, lives with his good-natured wife Ani Lhamo, son Tsering, and daughter-in-law Chamo Cham. Chamo Cham is clever and hardworking, and has a loving relationship with Tsering. But, she also loves to gossip, which sometimes causes tension between her and Akhu Nyima.

One day, a man claiming to be a tulku, a reincarnated religious master, shows up at Akhu Nyima's house, much to Akhu Nyima's delight. "This arrival of a lama Tulku to our home is a sign of my good karma and the great merit of our family!" he thinks to himself (Bhum 1994: 198). The tulku is vague about his background, and the narrator makes it clear that something is fishy about the tulku, but Akhu Nyima has complete and utter faith in the tulku. Even when Akhu Nyima thinks he catches the tulku getting basic facts about Tibetan religious history mixed up-the tulku at one point claims that "Milarepa cultivated Je Tsongkhapa as a teacher" (ibid: 201), a claim that would have been laughably wrong to anyone even passingly familiar with Tibetan Buddhism-Akhu Nyima is so full of respect for the tulku that he decides that it must be he who is mixed up and not the tulku. For doubting the tulku even for a moment, "he confessed and repented in his mind" (ibid: 201).

While Akhu Nyima is immediately and utterly devoted to the tulku, not all of his family members are as quick to give him their complete loyalty. Tsering asks the tulku about rumors about monasteries reopening and pilgrimage resuming because of the Communist Party's new policies around chö. "Truly, the policy of religious freedom is good!," he declares (ibid: 209). The tulku bristles at Tsering's statement, and says that Tsering shouldn't trust such people. He tells Tsering not to mention it again, and quickly changes the subject to "What is important for us chö practitioners is the chö that is for the next life" (ibid: 210).

Akhu Nyima makes Chamo Cham swear not to tell anyone about their honored visitor, but she inadvertently slips up and tells her close friend Druk Mo. Druk Mo is old enough to be married, but has been staying at home to care for her sick mother rather than focusing on marriage. Chamo Cham suggests: "If you do a ritual for your mother's illness, maybe it will get better" (ibid: 205). That would allow Druk Mo to take a husband without shirking her family 
responsibilities. They discuss these possibilities a little too loudly while fetching water from the village well, and soon the whole village knows that a tulku is staying with Akhu Nyima.

Upon this discovery, a number of elderly villagers show up at Akhu Nyima's house to investigate. Some are faithful, and request blessings from the tulku, but others are skeptical, and want to know why a high-ranking figure like a tulku would show up at their backwater of a village. They demand to know more about the tulku and his origins. The tulku skillfully sings a song in the style of Tibetan religious virtuosos, and wins over all but the most skeptical villagers. They request that he give a teaching on the four 'seals' of Buddhist doctrine, and it appears as though the tulku's fraud will be found out. However, he deflects the request for a teaching by telling them that elderly people should not concern themselves with such topics. He says: "How is it possible that I, who have mastered the study of the five texts, could not know about the four seals of view? However, you old people are the sun on the mountain top, the shadow below the mountain pass. Your next life will come tomorrow or the day after tomorrow, so say mani and attain good merit. How could these seals help you?" (ibid: 216). The ruse works, and the tulku maintains his standing.

Druk Mo invites the tulku to her house to do a ritual for her ailing mother, but the tulku only mumbles a few prayers before making it clear that his real focus is Druk Mo. He tells her that all important lamas and tulku take consorts, and that his teacher had told him in a dream that Druk Mo was his karmic life partner. Though Druk Mo initially resists the tulku's advances, the tulku manages to convince her with these arguments, and the two begin an affair. Druk Mo believes that the tulku will marry her, and arranges to send a necklace as a lover's gift via Chamo Cham. The next day, however, the tulku disappears, and with him, Druk Mo's necklace and several of Akhu Nyima's family's valuables.

Suspicion falls on Chamo Cham for having seduced the tulku and orchestrated the theft, and she endures a painful month of social ostracism: "A month is a fairly short period of time, but for Chamo Cham, it felt as long as a year. For that month, the topic of conversation of every person in the village was Chamo Cham. The rumors pierced her ears and the public gossip squeezed her heart" (ibid: 229). Eventually, however, Chinese police manage to catch the tulku, restoring both Chamo Cham's name and the stolen goods. The story ends with a speech by the policeman, who says that Communist Party policy is to respect freedom of chö, but that they must be wary of fraudulent chö taking advantage of the people. The onlooking crowd nods their heads at the policeman's sage advice, and the story ends with "a tear coming down from Chamo Cham's eye" (ibid: 233).

\section{Reception of "Tulku”}

When the story was published in sBrang Char in 1981, it immediately attracted controversy. Many Tibetan readers took the representation of a counterfeit tulku to be a criticism of the tulku system as a whole and praised or denounced the story based on that interpretation. Pema Bhum's introduction to Dondrup Gyel's collected works describes Gyel being called bad names (ming ngan), such as heretic (log lta) and destroyer of the teachings (bstan gshig) by Tibetans who felt that his story was inappropriate for the circumstances at the time (Bhum 1994: 26). Presumably, Tibetans who had just undergone the hardships and privations of the Cultural Revolution were incensed at what they saw as one of their own attacking beloved cultural institutions such as the tulku system. This may have been felt as a particularly painful blow because Tibetans were not able to speak publicly about political matters, and so, as Tsering Shakya puts it, "a large portion of the populace favored the use of tradition as a way to restore Tibet's selfhood and define it as separate from China" (Shakya 2000b: 37). Bhum notes that Gyel even received death threats and a razor in the mail from some local tantric practitioners, who were said to have cast a powerful curse against him. Gyel, for his part, seems not to have been afraid of these attacks, and joked about checking the book they used to curse him out from the library (Bhum 1994: 26-27). ${ }^{5}$

However, there do seem to have been Tibetans that also supported Gyel's criticism of corrupt tulku, particularly younger Tibetans who shared some of the Communist Party's criticisms of traditional Tibetan society. For example, Lauran Hartley notes, based on oral interviews, that there seems to have been a generational divide in the reception of "Tulku." One informant told her that about seventy percent of students agreed with the maverick writer, while sixty percent of older teachers (at a secular institution) openly opposed the story (Hartley 2003: 227). Those who supported the story may have seen it as usefully and realistically depicting the hardships faced by Tibetans in the past. These younger thinkers may not have agreed with the Party's program of reforms for Tibetans, but they also thought that Tibet could not simply return to the traditional system, and must find a way to modernize. 


\section{Scholarship on "Tulku"}

Considering Dondrup Gyel's reputation as the father of modern Tibetan literature, relatively little work has been done on "Tulku," and scholars seem puzzled on how to interpret the short story.

Some, such as the Amdo scholar Alag Dorzhi (Dor zhi gdong drug snyems blo) try to understand Gyel by placing him in a long Tibetan tradition of iconoclasm and skepticism about high figures such as tulku (Kapstein 2002: 100). Alag Dorzhi cites verses from several honored religious figures that criticize "play actors masked as scholars and saints" (Kapstein 2002: 101). Alag Dorzhi thus emphasizes Gyel's continuity with Tibetan tradition rather than seeing him as making a radically modern critique. Gyel, on this reading, was not criticizing the tulku system or traditional Tibetan religion as such, but poking fun at the high and mighty figures at the top of the Tibetan religious hierarchy while calling attention to bad apples within the system. Matthew Kapstein agrees that Gyel's criticism of the tulku system draws on traditions of skepticism about high-ranking figures of any sort, but he is less quick to assimilate "Tulku" into traditional literary forms. He seems to regard "Tulku" as an anti-clerical critique made by a layperson rather than a skeptical critique made from within Buddhist institutions (Kapstein 2002: 110).

Other scholars discuss "Tulku" in larger works on modern Tibetan literature. They often note the controversy over "Tulku," but say relatively little about their own interpretation of what to make of Gyel's corrupt tulku and whether he is meant to represent Tibetan religious institutions more generally, or whether he is a lone corrupt figure. Pema Bhum, for example, describes "Tulku" and its reception in both the Tibetan-language introduction to Gyel's collected works (Bhum 1994) and in an Englishlanguage biography of Gyel on Treasury of Lives (Bhum 2016), but does not dwell on the interpretation of "Tulku." In Chinese Influences on Modern Tibetan Writings: A Study of Selected Writings of Yidam Tsering and Dhondup Gyal, Sonam Dolkar summarizes "Tulku" and describes the negative reaction it received. Dolkar asserts that Gyel “wasn't actually criticizing any Tibetan lama or trulku" and so does not necessarily represent a critique of the system as a whole (Dolkar 2019: 50). However, she also admits that "To a certain extent, we must accept that Gyal was a non-believer in Tibetan Buddhism," and that the story represents "suspicion" of high religious figures in general (ibid: 50). Lauran Hartley, writing about Tibetan literature from 1980 to 2000, discusses "Tulku" briefly, focusing more on the controversy than on the story itself. In a footnote, however, she writes that the story is "most likely a straightforward plot written along the lines of more standard exposes" (Hartley 2003: 227). She notes that 1979 and 1980 saw a number of stories in Chinese literature more broadly that exposed official corruption, and places "Tulku" in that lineage. Christopher Peacock, writing recently in a dissertation about Chinese and Tibetan literature, sees it as a criticism of the Tibetans', (and particularly elder Tibetans'), "blind faith" as well as their "unquestioning obedience and mental stagnation" (Peacock 2020: 88). Gyel, on Peacock's interpretation, welcomed the increasing freedoms that came with the end of the Cultural Revolution, but did not want Tibetans to return uncritically to an imagined traditional past.

However, while most of these scholars take "Tulku" to represent a criticism of the tulku system, a criticism of the blind faith of the Tibetan people, or simply of the corrupt tulku portrayed in the story, at least one scholar has suggested a hidden meaning buried in "Tulku." Specifically, Tsering Shakya suggested that "a closer reading of the text-in light of the recent history of Tibet and China-might suggest that the figure of the incarnate lama represents the blind trust that people had placed in Mao and the Communist Party" (Shakya 2000a: 39). He does not develop this point beyond merely mentioning it in passing, but seems to be suggesting that "Tulku" represents a warning to Tibetans that multiple parties might try to use the mask of religion to deceive them.

In each of these cases however, scholars spend only a few pages at most discussing "Tulku," and base their interpretations on the overall plot rather than a detailed analysis of the language of the short story. My reading picks up on Shakya's suggestion, and develops this reading based on a close textual analysis.

\section{Uses and Misuses of 'Chö' in "Tulku"}

With all of this in mind, I propose to examine "Tulku" by looking at Gyel's use of the word chö in "Tulku." Who uses the term, how, and to what ends? I argue that attention to chö will give us insight into one way of interpreting Gyel's message in "Tulku." But, to understand why that is, we should first take a closer look at the term itself.

The term corresponds to the Sanskrit term dharma, itself notoriously difficult to translate, and can thus refer to the Buddha's teachings, religion generally, phenomena, moral law, truth, or reality. It is also not necessarily reducible to purely Indic meanings, as indicated by Tibetan terms such as mi chö (mi chos) that refer to worldly principles or customs. Steven Collins, writing about dhamma, the Pali rendering of the same term, notes that the meaning of 
dharma is internally contested in Buddhist traditions. He argues, therefore, that dharma/dhamma is best translated somewhat ambiguously as "what is right" (Collins 1998: 419-420). Such a translation brings out the normative claim implicit in any use of the word dharma. When someone uses the term dharma, they are often making a claim about what is right, and authorizing themself the sort of person who knows what is right. We should also note that chö is tied up with dynamics of exclusion and belonging, particularly in Tibet. The term for Buddhism in Tibet is nang chö (nang chos) - the religion of the insiders-with religious practitioners referring to themselves as nang $\mathrm{pa}$-s or insiders.

In order to reflect this possible range of meanings of chö, I will mostly leave the term untranslated, and instead unpack the meanings that it has in context. However, it is important to remember the claims to normativity and inclusion so frequently implied by chö.

Chö, and its necessary questions, are central to "Tulku." This tale of a false tulku and his eventual capture by the police raises fundamental questions: who gets to be the representative of chö and who gets to control it? How can ordinary people tell good chö from bad? Is the Chinese government a threat to chö, or its protector?

The word chö occurs twenty-two times in "Tulku," and is spoken most often by the tulku (eight times), followed by (representatives of the Communist Party (four times)), narrator more than party reps (the narrator (six times, often describing the tulku)), Akhu Nyima (one time), Tsering (one time), and the crowd of Tibetan villagers that gather to see the tulku (two times). What is immediately striking about this breakdown is how rarely the Tibetan villagers in the story use the word, even though the story largely centers on them. Rather, it is spoken by outsiders to the Tibetan villagers, very frequently in order to convince them of something, and in particular to make a claim that the speaker is part of the group, so to speak, with the implication that other parties are not part of that group.

\section{The Tulku's Performance of Chö}

Far and away, the term chö is used most often by the tulku or by the narrator describing the tulku's activities. This type of usage occurs eleven times, fully half of the usages of chö in the short story, and can be broken into three identifiable patterns.

First, the tulku uses the term 'chö practitioners' (chos pa rnams) twice, in each case to identify himself as part of a group with the Tibetan villagers and define the Chinese government as outsiders. In each case, moreover, he asserts this identify following a challenge to his authority. In one case, Tsering relates how the Party is now allowing Tibetans to visit monasteries, and praises the "Party's policy of religious freedom (tang gi chos dad rang dbang gi srid jus de legs po 'dug)" (Bhum 1994: 209). This statement momentarily ruffles the tulku, but he soon recovers and dismisses Tsering's opinion by changing the subject to "what's important for us chö practitioners (nga tsho chos pa rnams la nye bar mkho ba ni...)" (ibid: 209). This implicitly draws a line which includes and elevates tulku and Akhu Nyima's family, excluding the Chinese.

In the other case, when Akhu Nyima startles the tulku by asking about his background, the tulku is similarly rendered speechless for a moment, but then sidesteps Akhu Nyima's question by launching into a discussion of how "in this degenerate age, chö practitioners are cut off from dharmic destiny, and even lamas don't have any freedom (snyigs ma'i dus 'dir chos pa rnams kyi chos skal chad pa dang/ bla ma rnams kyang rang dbang na min 'dug)” (ibid: 199). In context, it is clear that the tulku is suggesting that the Chinese are responsible for this particularly degenerate age. So, again, when his backstory is being questioned, he responds by asserting himself as part of the imagined group of chö practitioners with Akhu Nyima and placing this group in opposition to the Chinese. The tulku does not explicitly contrast nang chos with phyi chos ('insider religion/Buddhism' with 'outsider religion/ non-Buddhism'), but this distinction, and the valuation that accompanies it, underlies much of what he says.

The second main way in which the tulku uses chö is to invoke the sequence of rebirths and thereby place himself and his audience in a temporal context that spans multiple lifetimes. Such usages include discussion of his own karmic lot, chos skal, (used to mean something like fate or destiny) (ibid: 199, 215); referencing people with whom he has a chö connection, chos 'brel, (a connection between two people that runs across lifetimes) (ibid: 199); or declaring the importance of the chö necessary for the next life tshe phyi mar dgos pa'i chos, (doing virtuous things now so as to secure a good rebirth) (ibid: 199). Each usage thus refers to the idea, fundamental to Buddhism, that what we conventionally refer to as a person goes through a series of rebirths, where present reality is largely determined by past action (karmic lot or karmic destiny, making chö connections), and present actions determine the quality of the future life (religious practices for the next life).

By using chö in this way, the tulku calls forth a particular worldview and set of values on the part of his audience, 
and primes them to frame their actions, (and their interpretation of his actions), in terms of this worldview. Specifically, he invokes a Buddhist cosmology that traces actions and consequences over the course of multiple lives, inviting his audience to think about their present actions in terms of this longer future. In doing so, he implicitly rejects the materialist worldview advocated by the Chinese government, which tends to focus more on the present life. Not coincidentally, this frame of reference highlights the tulku's claim to authority, for what makes tulku special is their mastery of the sequence of rebirths, since they are accomplished enough to be able to choose their rebirth and compassionate enough to choose a human body that can help those still unenlightened. By continually referencing the sequence of lives, the tulku highlights his own status as someone who has mastered rebirth and his qualifications as someone who deserves respect and deference.

This is most clear in the example where the tulku discusses "religion for the next life." Again in response to Tsering's news of Communist tolerance of monasteries, the tulku says: "If such things are happening now, well then there's nothing wrong. But I don't trust it (da lta'i gnas tshul 'di lta bu yin na mi legs rgyu mi 'dug mod/ 'on kyang nga rang de la yid ches rgyu mi "dug)" (ibid: 209-210). Changing the subject abruptly, he declares the importance of the "chö necessary for the next life (tshe phyi mar dgos pa'i chos)," emphasizing the importance of the sequence of rebirths over the potential benefits offered by the Communist Party in this lifetime (ibid: 210). The tulku thus stresses an alternative value system, one within which he has more claim to authority.

Finally, the third way the tulku deploys the term chö is to associate himself with religious topics and phenomena. He discusses religious hermitages (chos dgon) (ibid: 200), speaks about religious topics (chos phyogs) (ibid: 199) with Akhu Nyima, references Tsongkhapa the religious king (chos kyi rgyal po) (ibid: 201), and performatively recites texts or mantras-literally 'recites chö' (chos bton and chos 'don) (ibid: 218). Once again, he consistently brings up topics related to the religious worldview within which he commands authority. This is in spite of the fact that he consistently seems unable to keep his own facts straight about his backstory or about Tibetan Buddhism itself.

This is a textbook example of the sort of discourse Bruce Lincoln defines as something "strategically employed to mystify the inevitable inequalities of any social order and to win the consent of those over whom power is exercised" (Lincoln 2014: 4). Akhu Nyima does not resent the fact that a chubby stranger has turned up at his door expecting special treatment. Rather, because Akhu Nyima fully accepts the Buddhist ideological system that accords high status to tulku, he consents to the tulku's presence, and indeed, considers it an honor that a tulku would stay in his house.

The tulku does not invent this chö-discourse, by any means, nor does he do all the work of positioning himself as someone who controls chö. Rather, he finds willing collaborators among the Tibetan villagers. Akhu Nyima, of course, is explicitly portrayed as gullible, but the other villagers who crowd around to see the tulku are also eager to recognize the tulku as a religious authority. Some ask skeptical questions about his origins or about his knowledge of the Buddha's teachings, but for the most part they accept him readily, asking him to explain the Buddha's chö (sangs rgyas kyi chos lugs) (Bhum 1994: 215) and to give them a talk on chö (nga tsho la gsung chos zhig gnang rgyu sku mkhyen) (ibid: 216).

Strikingly, these two instances are the only times when the Tibetan villagers use the word chö. The tulku is constantly framing himself as an authority on chö in order to enhance his authority in the eyes of the Tibetan villagers, but the villagers rarely question his knowledge of chö. Indeed, the only time when the villagers themselves use the term is to ask the tulku to give them a discourse on chö. Such a request, which is framed in high honorific language, acquiesces to the tulku's framing of their encounter as a high-ranking teacher meeting lowly students. The villagers portray themselves as lacking in knowledge about chö and therefore in need of instruction by an expert such as the tulku. So, while Gyel portrays the tulku as ostentatiously framing himself as a master of chö, he also portrays the villagers as receptive to his claims. The tulku wants to be taken as a credible religious authority, and the villagers are only too willing to accept him as such.

With this willing participation on the part of the villagers, the tulku successfully deploys chö-discourse in order to secure the approval of Akhu Nyima and the other villagers. Even when the word chö itself is not used, the tulku uses pseudo-religious explanations at other key moments, such as when he is trying to seduce Drukmo (my lama prophesied you in a dream!) (ibid: 222$)^{6}$ or when he clearly cannot answer a doctrinal question posed by the crowd (of course I know about the four seals of view! But you old people might die any day, so you should really focus on making merit instead!) (ibid: 216). ${ }^{7}$ Throughout the story, whenever an opportunity arises for the Tibetans to doubt the tulku's authenticity, whether because he is a stranger, lacks doctrinal knowledge, or is proposing something 
seemingly inappropriate, the tulku wards off such doubts with copious and skillful use of chö-discourse.

The tulku's mastery of this discourse is not limited to the words he uses. In fact, it seems clear that this is one of the weaker aspects of the tulku's act. Talking with Akhu Nyima, the tulku maintains that Milarepa had studied under Tsongkhapa, a statement educated Tibetans would have found laughably wrong. This arouses the suspicions of even the credulous Akhu Nyima, but he decides that it is he who is mixed up, not the tulku. As Lincoln notes, "whether the discourse is persuasive or not... is only partially a function of its logical and ideological coherence" (Lincoln 2014: 8). Rather, a whole constellation of factors of rhetoric, appearance, and performance contribute to the tulku's success. When he prays in front of Drukmo, the tulku is merely mumbling "Om Om Om," interspersed with words like "Buddha" and "lama" (Bhum 1994: 218-219). Indeed, when a group of villagers shows up at Akhu Nyima's house to investigate the tulku, it is his ability to sing a song in the style of famous lamas-a signal of his mastery of chö discourse-that clinches his acceptance into the community.

In his portrayal of the fraudulent tulku, then, Gyel skillfully portrays someone who performs the discourse of religion in order to take advantage of the faith of Tibetan villagers. Surely, as many readers and scholars have already noted, Gyel was finely attuned to the dangers of religion being used this way, and critical of those whose faith outruns their common sense such that they could be fooled by a fraud like the tulku. The story, under this interpretation, is a cautionary tale about the dangers of religious ideology being used to exploit the masses. One could even read it to criticize the tulku system more broadly, with the implication that the difference between the story's tulku and other tulku is one of degree rather than a difference in kind. This has certainly been the standard interpretation of "Tulku."

\section{The Party's Chö Discourse}

I argue, however, that if we consider "Tulku" from another angle, we can see Gyel making an additional, and even more subtle, point about the uses and abuses of chö. Namely, that it is not only the tulku who uses chö-discourse to attempt to sway the Tibetan villagers to his side, but also the policeman who catches the tulku, and who is portrayed as a representative of the Chinese Communist Party (CCP). Though Gyel does not overtly criticize the Party-the story would not have made it past the censors if he had-the way the policeman uses chö-discourse parallels the way that the tulku uses it, and suggests a linkage between the tulku and the policeman. We can thus read "Tulku" as Gyel's subtle suggestion that both the tulku and the Chinese Communist Party use discourses of chö in order to appeal to the Tibetan villagers. On this reading, Gyel is attuned to the ways in which religion is a contested category that multiple sorts of actors-not just the tulkumanipulate to their own advantage.

This interpretation of "Tulku" as a warning about the dangers of both the fraudulent tulku and the CCP deploying chö-discourse requires reading between the lines, a practice that is dangerously close to arguing from silence. After all, the policeman is ostensibly the hero of Gyel's story-he is the one who apprehends the fraudulent tulku and returns the stolen goods to Akhu Nyima and Druk Mo. Gyel places the final, heroic speech in the mouth of the policeman, and has the policeman deliver the (clearly true) message that some people only wear "the outer clothing of chö (chos lugs kyi phyi gos)" and that the villagers must therefore be careful (Bhum 1994: 213). This is the moral that Gyel wants readers to come away with, so one could ask why he would he put it in the mouth of a CCP policeman if his intention was to criticize the Party as well.

However, there is textual evidence to suggest that Gyel sets up the tulku and the CCP as opposite, yet parallel figures. They are linked in two key ways. First, by the fact that they repeatedly place themselves in opposition to one another. And second, by their use of chö-discourse to portray themselves as allies to the villagers in ways that exclude the rival figure. This parallelism highlights the ways that both claim authority on the basis of religion, and use it to secure their own power vis-à-vis the Tibetan villagers.

First, Gyel repeatedly places the tulku and the CCP in opposition to one another. We have already seen how the tulku reacts to Tsering's praise of the Party's policy of religious freedom by criticizing the Chinese and saying he does not trust them, before asserting that chö for the next life is what is important. Similarly, the policeman tells the Tibetan villagers that they must beware. The policeman tells the Tibetan villagers that they must not trust "those who wear the outer clothes of chö (chos lugs kyi phyi gos)" and must distinguish between friend and foe, clearly implying that he and the Party are the friend, while the tulku is the foe (ibid: 213). The whole narrative structure of the tulku defrauding the villagers and the policeman uncovering him places the tulku and the policeman as opposing, but related figures. Each stands outside the boundary of the Tibetan village trying to win the 
allegiance of the villagers at the expense of the competing claimant to their favor.

Second, they each use chö as a key part of their strategy to win over the villagers. We have already seen how the tulku does this, but now we should turn to the ways in which the CCP policeman uses it. Though the policeman is only in the story for a short while, he uses the term chö four times. In addition, as we have already seen, Tsering mentions chö when describing the party's policy of religious freedom (tang gi chos dad rang dbang gi srid jus), approvingly restating the CCP's claims to protect religious freedom (ibid: 213) of protecting. Each of these uses takes the Chinese government, and the Chinese people generally, who initially seem to be regarded with some wariness, and reframes them as positively associated with chö. It portrays them, as well, as being in a position to adjudicate disputes about chö.

For instance, when the policeman apprehends the tulku, he wins the approval of the assembled villagers by giving a speech in which he declares: "When we implement the party's policy of religious freedom, you must distinguish well between friends and enemies" (Tang gi chos dad rang mos kyi srid jus lag len du bstar skabs/ ci nas kyang dgra gnyen gyi dbye ba legs por 'byed dgos) (ibid: 213). This statement frames CCP policy as positively associated with freedom, tolerance, and respect. The policeman seems to be assuming that the Tibetan villagers care about religion, and will be grateful to the Party for allowing religion to be practiced more freely. And yet, it also suggests that there is a danger to religion, and that an increase in religious freedom may lead to the appearance of 'enemies' like the tulku who seek to take advantage of the religious beliefs of Tibetans.

This sense is amplified when the policeman says that some people only wear the outer clothing of chö (chos lugs kyi phyi gos) (ibid: 213). As such, religion needs to be managed. The policeman tells the villagers that they should attempt to tell friends from foes and distinguish those merely wearing the outer clothing of chö from those who are true religious practitioners. But, he also suggests that he, the policeman, is the one who is ultimately able to do this. In the policeman's statement, the state charges itself with the duty of protecting the public from the natural excesses of religion, policing its boundaries and apprehending frauds like the tulku.

The policeman also uses chö-discourse to claim authority over religion when adjudicating a dispute between Akhu Nyima, who remains a devout Buddhist, and Guru Dorje, a Bön practitioner who needles Akhu Nyima over having been tricked by the false tulku. As the two old men start to fight, the policeman says: "That's enough! (da chog gi chog gi)" (ibid: 232). He tells the squabbling old men that, according to the Party's policy of religious freedom that he had just mentioned above, people of different religious traditions must respect one another (tang gi srid jus ltar na chos lugs kyi grub mtha' khag bar phan tshun brtsi 'jog byed dgos pa las smod pa tang mi chog pas) (ibid: 232-233) and that one should have faith in one's own religion without criticizing others (dad pa yod na rang rang gi chos la dad pa byos) (ibid: 233). Once again, these statements portray the Chinese government as a friend to religion, and of supporting religious liberty and respect for different religions. At the same time, however, these statements place religion in a bounded category governed and superseded by the state. When Akhu Nyima and Guru Dorje start to fight, the policeman takes it as his duty to resolve the dispute and ensure that everyone is following the rules laid out by the state.

Such a position relativizes religious goals and values within the state system. This stands in contrast to the tulku, who constantly made reference to the sequence of lives as forming the field within which actions derived their meaning. When the tulku talks about "what's important for us religious practitioners is the religion for the next life" (ibid: 210), he says it to discredit Tsering's positive reports about Communist policy and to emphasize a value system according to which a figure such as himself has more authority than the temporal government. When the Communist policeman says that under "the party's policy of religious freedom, you must distinguish well between friends and enemies" (ibid: 213), he is promoting the justice of Party policy and discrediting the tulku.

In each case, the speaker separates an 'us' (us, chö practitioners, friends) from a 'them' (the Communists allowing people into monasteries, enemies), placing himself in the group with the Tibetan villagers and excluding the competing authority. In using chö in this way to both frame himself as a friend to the Tibetan villagers and exclude the tulku, the policeman demonstrates that he, too, has mastered a particular discourse of chö. But, in this chö-discourse, it is the Party rather than the tulku who claims authority over chö.

Both the tulku and the policeman thus use chö in order to appeal to the Tibetan villagers, claim power for themselves, and exclude the opposing party. As such, while "Tulku" only exposes the tulku himself as explicitly fraudulent, there are grounds for reading similarities between the ways in which the tulku and the Party use chö to appeal to and manipulate the Tibetan villagers. While censorship 
meant that Gyel could not criticize the Party directly, this reading suggests that he subtly subverted such censorship by deliberately creating parallels between the Party and the tulku that suggest that both must be treated with skepticism and caution. Gyel was critical of Tibetan villagers' credulity, and of the hierarchical clerical structures of Tibetan Buddhism which take advantage of this credulity. But, he also showed skepticism towards the Chinese government's promises of religious liberty, and hinted that they might be as fraudulent as the tulku himself. At the very least, we can read his story as urging skepticism towards those who would claim control over chö and use such claims to gain control over Tibetans.

\section{Conclusion}

While it is impossible to know Gyel's true intentions while writing "Tulku," and to prove that he set out to criticize the Chinese government, this reading has the potential to shed new light on Gyel's understanding of the need for Tibetans to modernize.

On this interpretation, Gyel is sensitive to the various ideological dimensions of chö and the way that it can be weaponized by multiple parties. The story suggests that it is not the case that Tibetans are either dominated by traditional Tibetan religious ideology or Communist Party ideology. Rather, Gyel notes how both ideologies are operating at the same time and trying to make claims on the Tibetan villagers. We can thus see the tensions in "Tulku" as the struggle between two counter-ideologies to win legitimization in the eyes of the Tibetan villagers. Both appeals to the Tibetans are attempts by "elites and of those professionals who serve them... to win the consent of those over whom power is exercised," to borrow Bruce Lincoln's characterization of ideology (Lincoln 2014: 4). As such, the appeal is made on the basis of an assumed value or interest of the targets of that appeal-in this case: religion.

In contrast to interpretations which take Gyel's "Tulku" to be an attack on the tulku system or the Communist Party, we should read the story as warning about how multiple parties invoke chö in making appeals to Tibetans and cautioning skepticism towards all such claims. Beware those who seek to win your loyalty with a religiously inflected sales pitch, he would then be saying. Because, even though someone is claiming authority over chö, in a contested field, the term alone is empty. We should recall the point in "Tulku" when the villagers show up at Akhu Nyima's house to investigate the tulku. Akhu Nyima silences one heckler by asking: "What are you doing asking about roots and branches, and not necessary questions of
Catherine Hartmann, PhD, is Assistant Professor of Buddhist Studies in the Department of Philosophy and Religious Studies at the University of Wyoming. Her central research centers on the goal of transforming perception in Tibetan pilgrimage literature, although she is also maintains interests in Buddhist ethics, issues of Buddhism and addiction, and contemporary Tibetan fiction.

Thank you to Anne Monius, who provided early guidance on this work, to Naga Sangye Tendar, whose reading of "Tulku" provoked a great deal of thought, and the attendees at the Yale Himalya Conference in $\mathbf{2 0 1 4}$ who provided useful feedback. Many thanks as well to the Robert H.N. Ho Family Foundation for supporting this research.

chö?" (Bhum 1994: 213). It is good advice, even if Akhu Nyima himself does not follow it. Indeed, it is the failure to ask such "necessary questions of chö" that leads to all the trouble, and so the solution, Gyel seems to suggest, is to ask those necessary questions. Given that chö is something that can no longer be uncritically followed, Tibetans must therefore take the important project of modernization into their own hands, re-evaluating what counts as chö and who gets to control it.

\section{Endnotes}

1. Khyod kyis zhu dgos pa'i chos mu zhu bar/rtsa ba dang yu ba dris nas ci bye.

2. For additional history on the development of modern Tibetan literature, see Hartley and Schiaffini-Vedani 2008.

3. This is not to say that Tibetan culture was entirely religious. Scholars of Tibetan culture have long tended to downplay or disregard non-religious aspects of Tibetan life, a fact that results from scholars' primary interest in Buddhism and from Buddhism's dominance in the historical and literary archive. However, this neglect of Tibet's non-religious culture, (what some may call "the secular," although this terminology is contested), has recently been challenged.

4. For instance, the arranged marriage practices explored in "Frost-Bitten Flower."

5. Yig skogs kyi nang du kha spu bzhar gru bzhag nas khong la bskur te gsod brda gtong ba dang / lung tshan re zung gi sngags pa rnams kyis khong la dmod mthu gtong gi yod pa'i skad cha yang grags/ skabs 'di dag tu nga tsho thengs "gar thug rgyu byung / ngas khong bod spyi tshogs la thugs pham cung tsam byung yod nges snyam yang / thugs pham lta zhog thugs spobsje 
cher gyur 'dug khong gis sngags pa 'ga' res khong la mthu rgyag gi yod skad kyang / de la zhed don ci yang med/ khong tsho' $i$ mthu gtong byed kyi dpe cha ni/ zhi khro rab 'byams zer ba zhig yin skad la/ de ni khong gis kyang dpe mdzod khang nas btsal te klog chog ces dang.

6. "A few days ago in my dreams, my excellent lama appeared in the sky. I dreamed that he told me that tomorrow, I would meet a good sort of dakini, and the next day, at Akhu Nyima's house, I knew it referred to you. How could a lama's prophecy be wrong? Even our meeting today is karma. (Nyin 'ga'i sngon la nga'i rmi lam du bla ma dam pa rnam mkhar byon te/ sang nyin khyod rigs bzang ski mkha' "gro ma zhig dang "phrad par "gyur ro zhes gsungs pa zhig rmis pas/ phyi nyin khyod a khu nyi ma tshang la bslebs ma thag/ nga'i sems la bla ma'i lung bstang de khyod la babs pa shes song/ bla ma'i lung bstan la 'khrul ba zhig gang na yod)."

7. "How is it possible that I, who have mastered the study of the five texts, could not know about the four seals of view? However, you old people are the sun on the mountain top, the shadow below the mountain pass. Your next life will come tomorrow or the day after tomorrow, so say mani and attain good merit. How could these seals help you? (Nga gzhung po ti lnga la gsan sbyong mthar phyin pa zhig gis lta ba bka' btags kyi phyag rgya bzhi mi shes pa ga la srid/ yin na yang/ khyod rgan po ri rtse'i nyi thig la rtings gi grib ma/ tshe phyi ma la sang 'gro gnangs 'gro yi mi yin pas/ kha ma Ni re thon la dge rtsa sgrubs/ phyi rgya phyag tshos khyod la phan thogs rgyu ci yong)."

\section{References}

Bhum, Pema, ed. 1994. Lang tsho'i rbab chu dang ljags rtsom bdams sgrig. Tibetan Literature Series 2. Dharamsala: A myes rma chen bod kyi rig gzhung zhib 'jug khang.

Collins, Steven. 1998. Nirvana and Other Buddhist Felicities. Cambridge: Cambridge University Press.

Dolkar, Sonam. 2019. Chinese Influences on Modern Tibetan Writings: A Study of Selected Writings of Yidam Tsering and Dhondup Gyal. Dharamsala: Library of Tibetan Works and Archives.

Gayley, Holly and Nicole Willock. 2016. "Introduction: Theorizing the Secular in Tibetan Cultural Worlds." HIMALAYA 36(1): 12-21.
Hartley, Lauran R., and Patricia Schiaffini-Vedani. 2008. Modern Tibetan Literature and Social Change. North Carolina: Duke University Press.

Hartley, Lauran R. 2003. “Contextually Speaking: Tibetan Literary Discourse and Social Change in the People's Republic of China (1980-2000)." Ph.D. Dissertation, Bloomington, IN: Indiana University.

Hartmann, Catherine and Sangye Tendar Naga, trans. 2013. “Tulku," by Dondrup Gyel. The Tibet Journal 38 (3-4): 35-55.

Huber, Toni, ed. 2002. Amdo Tibetans in Transition: Society and Culture in the Post-Mao Era Proceedings of the Ninth Seminar of the International Association for Tibetan Studies, Leiden 2000. Brill's Tibetan Studies Library; v. 2/5. Leiden: Brill.

Kapstein, Matthew. 2002. “The Tulku's Miserable Lot: Critical Voices from Eastern Tibet." In Amdo Tibetans in Transition: Society and Culture in the Post-Mao Era Proceedings of the Ninth Seminar of the International Association for Tibetan Studies, Leiden 2000, edited by Toni Huber, 99-111. Leiden: Brill.

Lin, Nancy. 2008. "Döndrup Gyel and the Remaking of the Tibetan Ramayana." In Modern Tibetan Literature and Social Change, edited by Lauran R. Hartley and Patricia SchiaffiniVedani, page numbers. Durham: Duke University Press.

Lincoln, Bruce. 2014. Discourse and the Construction of Society: Comparative Studies of Myth, Ritual, and Classification. New York: Oxford University Press.

Peacock, Christopher. 2020. "Intersecting Nations, Diverging Discourses: The Fraught Encounter of Chinese and Tibetan Literatures in the Modern Era." Ph.D. Dissertation, New York: Columbia University.

Shakya, Tsering. 2000. "The Waterfall and Fragrant Flowers: The Development of Modern Tibetan Literature in the People's Republic of China in the 1980s." Mānoa 12(2): 28-40.

— trans. 2000. "Waterfall of Youth," by Dhondup Gyal. Manoa 12(2): 9-13. 